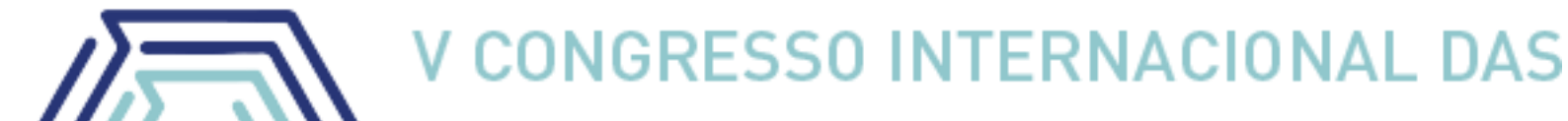 LICENCIATURAS COINTER - PDVL 2018
}

\section{AS DIFICULDADES APRESENTADAS COM O ENSINO-APRENDIZAGEM DE QUÍMICA}

\section{THE DIFFICULTIES PRESENTED WITH CHEMISTRY TEACHING-LEARNING}

\author{
Apresentação: Relato de Experiência
}

\begin{abstract}
Maria Grasielly Brandão Felix ${ }^{1}$; Thainá Maria da Silva Carvalho ${ }^{2}$; Rosiane Antonia Cavalcanti $^{3}$; Claúdio Henrique Alves Perdigão ${ }^{4}$; Sanderson Hudson da Silva Malta ${ }^{5}$
\end{abstract}

\section{DOI: https://doi.org/10.31692/2358-9728.VCOINTERPDVL.2018.00265}

\section{Introdução}

O desinteresse dos estudantes pela química é preocupante, apesar de ser uma disciplina bastante presente no dia a dia, os alunos a encaram como uma das piores matérias do ensino médio. Em atividades de extensão realizadas nas escolas, propostas como atividades integrantes do curso de Licenciatura em Química do IFPE - Campus Vitória de Santo Antão (IFPE-CVSA), foi possível conhecer o ambiente escolar e identificar que os alunos possuem muitas dificuldades com a disciplina de química. $\mathrm{O}$ ensino tradicionalista atrelado as aulas monótonas e outros fatores como falta de estrutura, por exemplo, estimulam ao desinteresse. A super lotação da sala de aula é um ambiente fechado e pequeno (Segue fotos em anexo mostrando o ambiente). $\mathrm{O}$ professor que ministra as aulas não tem formação em química, e sim em matemática, dificultando assim o ensino do professor e a atenção dos alunos, porque o docente não é muito familiarizado com os assuntos da disciplina exercida e sim na qual ele se formou.

Este relato foi realizado a partir de uma atividade extensionista numa turma de $3^{\circ}$ ano do ensino médio em uma escola da rede publica Estadual de Pernambuco, no município de Pombos.

\section{Relato de Experiência}

\footnotetext{
${ }^{1}$ Licenciatura em Química, IFPE Campus Vitória, grasiellybrandao@outlook.com

${ }^{2}$ Licenciatura em Química, IFPE Campus Vitória, thainamscarvalho@outlook.com.br

${ }^{3}$ Licenciatura em Química, IFPE Campus Vitória, rosiane.cavalcanti2016@gmail.com

${ }^{4}$ Especialista, IFPE Campus Vitória, claudio.perdigao@vitoria.ifpe.edu.br

${ }^{5}$ Especialista, IFPE Campus Vitória, sanderson.malta@vitoria.ifpe.edu.br
} 
A partir da observações durante a intervenção na escola em tela, deixa claro que os alunos apresentaram muitas dificuldades com alguns conteúdos de química, como estequiometria, balanceamento química e estudo de soluções. Também foi possível constatar que os professores que atuam na disciplina de química são formados em outras disciplinas, como, por exemplo, Biologia. Entre as observações, ficou claro o desinteresse dos alunos pelas aulas de química, uma das hipóteses, e após, diálogo com os sujeitos numa roda de conversa realizada em sala, que o desinteresse tem relação com as atividades realizadas em sala de aula pelo professor, muitos citam que são monótonas e não vêem a relação da química com o seu dia-a-dia. A consequência disso, é o baixo rendimento dos alunos na disciplina. Em outro momento, foi realizada uma roda de conversa com os professores que ministram a disciplina de química, os quais, relacionam os baixos rendimentos dos educandos, principalmente, a desatenção em sala e a falta de estrutura da escola (como super lotação da sala, salas abafadas, falta de laboratório e etc).

No momento da roda de conversa com os docentes, os mesmo relataram que não têm formações de professores que os estimulem para o uso de pedagogias mais avançadas e construtivistas, como por exemplo, o uso de jogos didático o softwares educacionais, por isso ainda empregam métodos tradicionais e apoiados na transmissão dos conteúdos (educação bancária). Devido a escola possuir um laboratório de ciências precário em regentes, equipamentos e etc., os professores afirmaram que não o utilizam, realizando as aulas de forma mais teórica, justamente por essa falta de estrutura e demais apontamentos aqui apresentados, não há nenhuma aula prática. Diante disto, é licito supor que já era de se esperar um rendimento baixo dos sujeitos.

Cabe ressaltar que também foi observado que o docente passa por um grande desafio e conflitos, pois é perceptível que mesmo não sendo professores da área, o mesmo querem dá um melhor para os alunos, o que seria a utilização de práticas pedagógicas e dialogadas para exposição do conteúdo relacionando os conceitos à realidade do educando, dando significado e importância ao assunto apresentado. Tal desafio requer a integração de disciplinas, conhecimentos específicos e qualificações humanas, como habilidades, competências, atitudes e valores. $\mathrm{O}$ educador não deve ser mais visto como detentor de todo o conhecimento, e sim como mediador nos processos de formação e desenvolvimento dos saberes prévios dos estudantes, conforme premissas dos PCN e lembrado por Pereira e Souza (2004, p. 193): 
do cotidiano dos alunos, permitindo a relação entre teoria e prática, dando significado às aprendizagens realizadas na escola, possibilitando que estas sejam úteis na vida, no trabalho e no exercício da cidadania.

Imagem 1: Turma do $3^{\circ}$ ano, Fonte: Própria Imagem 2: Laboratório de Química e Biologia, Fonte: Própria
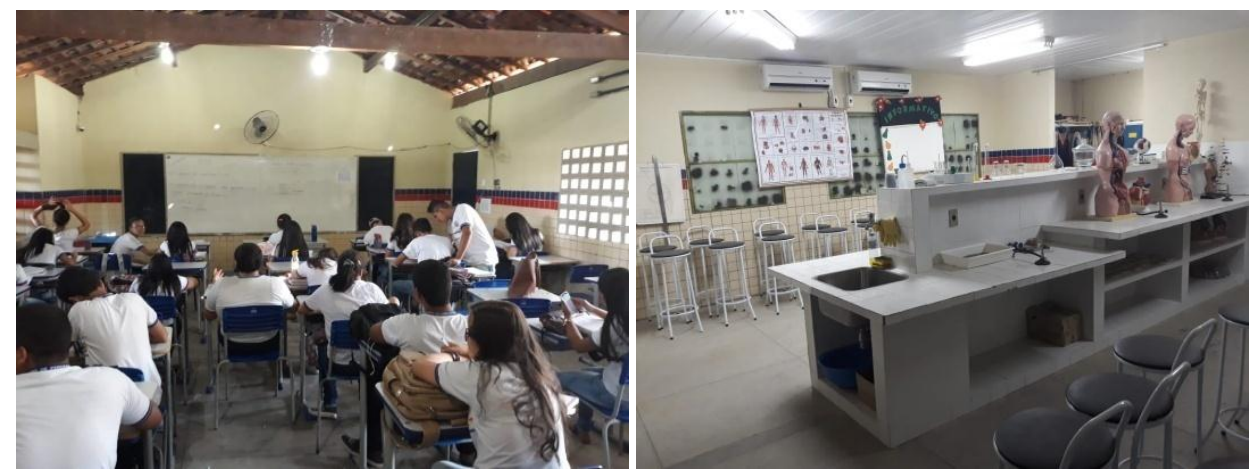

\section{Considerações}

O desinteresse dos estudantes por Química é alarmante na escola analisada, pois é uma reunião de vários fatores que envolvem aluno - professor - formação docente - estrutura física. Diante disso, é injusto responsabilizar apenas os docentes por eventuais falhas na qualidade de ensino pelos rendimentos baixos dos alunos, mas também é injusto responsabilizar os alunos por desatenção em sala quando falta de estimulo ao docente para práticas pedagógicas mais instigantes e inovadoras. A culminância das observações realizadas é que a ausência de formação dos professores é a chave para termos um ensino de melhor qualidade e um bom rendimento dos alunos. Convém observar que a estrutura física também é um fator muito importante para o ensino.

\section{Referências}

PEREIRA, L. C.; SOUZA, N. A. Concepção e prática de avaliação: um confronto necessário no ensino médio. Estudos em Avaliação Educacional: revista da Fundação Carlos Chagas, São Paulo, n. 29, p. 191-208, 2004.

HOLMESLAND, I. S. Qualidade e equidade no acesso ao conhecimento: experiências de uma sociedade igualitária. Educação, Porto Alegre, ano 26, n. 50, p. 45-70, 2003.

KRASILCHIK, M. Prática de ensino de química. 4. ed. São Paulo: Ed. da USP, p.198, 2004. LIMA, KÊNIO. Análise da metodologia de ensino de ciências nas escolas da rede municipal de Recife. Ensaio: aval. pol. públ. Educ., Rio de Janeiro, v.14, n.52, p. 397-412, jul./set. 2006. 